\title{
Kentsel Hafızanın Sürdürülebilirliği: Bir Mimarlık Stüdyosu Deneyimi
}

\author{
Doç. Dr. İnci Basa
}

\section{Öz}

Başkalaşmak adına herşeyin paradoksal biçimde aynılaştığı günümüz kentlerinde, kentlilik bilincinin/kimliğinin oluşması ve korunması bir sorunsal olarak ortaya çıkmaktadır. Kent, sadece hızlı dönüşüm süreçlerini sindirememekten değil, kentlinin mekansal pratiklerinin değişmesine bağlı olarak da, hafızasını koruyamamaktadır. Kentsel hafıza geri kazanılamaz şekilde aşınmaktadır. Zihinlerdeki imtiyazlı konumlarına bağlı olarak, kültürel ve tarihi olanın sürdürülebilirliği kentsel gündemde yer alabilirken, bu kategoride görülmeyenin, örneğin endüstriyel olanın sürdürülebilirliği, daha ender gündeme gelmektedir. Bu yazı, kentsel hafızanın, kimliği değiştirilen eski bir endüstri bölgesini de himayesine alacă̆ı bir tutumun önermesi olarak bir mimarlık stüdyosu deneyimini aktarırken, kentsel heykellerin (ve konumlandıkları alanın) rolünü, Henri Lefebvre'in temsil mekanları kuramsal çerçevesinde tartışmaktadır.

Anahtar Kelimeler: Kentsel Hafıza, Sürdürülebilirlik, Kentsel Heykel, Temsil Mekanları

\section{SUSTAINABILITY OF URBAN MEMORY: AN ARCHITECTURAL STUDIO EXPERIENCE}

\begin{abstract}
Occurrence and preservation of urban consciousness/identity become noticeable as a problematic in today's cities, where everything paradoxically becomes same on behalf of being different. The city can not protect its memory, due to not only the difficulty of absorbing the fast transformation process, but also due to the changing spatial practices of the citizens. The urban memory becomes irreversably abraded. While sustainability of cultural and historical essences can occupy the urban agenda due to their privileged cognitive statuses, those outside these categories rarely become an issue. This article, as a proposition of a tendency which recognizes an old industrial area under transformation within the bounds of urban memory, conveys an architectural studio experience, and discusses the role of urban sculptures (and their sites) within the theoretical framework of Henri Lefebvre's representational spaces.
\end{abstract}

Keywords: Urban Memory, Sustainability, Urban Sculpture, Representational Spaces

Doç. Dr. Inci Basa, Orta Doğu Teknik Üniversitesi, Mimarlık Fakültesi,

Mimarlık Bölümü, Ankara. e-posta: basa@metu.edu.tr Tel: +90312 2102246 


\section{Giriş: Sürdürülebilirliğin Nesnel Tini Olarak Mekan ve Heykel}

"Kolektif olarak kentlerimizi üretirken, kolektif olarak kendimizi de üretiriz."

David Harvey (2002/2008: 196)

Kentlerin çok boyutlu niteliği ve akışkan varlığı düşünülünce, yalın bir kent sözcüğüne ne denli ağır bir görev verildiği daha iyi anlaşılır. Pek çok kavramı, siyasal, ekonomik, sosyal, kültürel, mekansal bağlamlarda ve farklı parametrelerle kapsayan bir gösterge olarak kent, gündelik yaşam, kültürel çatışma, kolektif hafıza gibi displinlerarası dinamiği olan kavramsal kurguları da cömertçe devreye sokar. Kamusal mekan, kentin kavramsallaştırılmasında, akademik çalışmaların yoğunlaştığı bir alanı işaret eder. Mimarlık disiplininin, fiziksel olduğu kadar, kavramsal olarak da şekil verdiği bu karmaşık olgu, bu çalışmada kentsel hafızanın sürdürülebilirliği bağlamında ele alınmaktadır. Bu genel çerçevenin sınırladığı tartışma, kentlerin hızlı bir dönüşüm/dönüştürme akılsalığıyla, giderek hafızasızlaştığı iddiasına odaklanmaktadır. Bu bakış açısıyla yazı, şu önermeyi yapmaktadır: mekansal açılımlar sunan heykeller, kentsel hafıza inşasının önemli bir bileşeni olarak öngörülebilir.

Kentsel heykeller, kamusal mekanların toplumsal nesneleri olmalarının yanında, mekan üretme sürecinin güçlü aktörleri olma potansiyeline sahiptir. Henri Lefebvre, Mekanın Üretimi (1974/2012) başlığını taşıyan başyapıt niteliğindeki kitabıyla, mekan kavramına çok katmanlı kuramsal bakış açıları ve yeni araştırma alanları sunar. Mekanı, (mekanın) karmaşıklığını tasfiye etmeksizin, anlamak üzerine kurguladığı üçleme, bu çalışmaya da arka planda eşlik etmektedir. Lefebvre'in bakışı, mekanı "mimarlar, plancılar tarafından soyut olarak tasarlanan (mekan temsilleri)", "semboller ve anlamlar üzerinden yaşanan (temsil mekanları)" ve "gündelik yaşam içinde algılanan (mekansal pratik)" kuramsal üçlemesi içinde devinimli bir toplumsal üretim olarak düşünmeye yöneltir (1974/2012: 38-39).

Lefebvre'e göre, mekan temsilleri üretim ilişkilerinin öngördüğü düzene, bilgiye, işaretlere ve kodlara bağlıdır. Bundan farklı olarak, temsil mekanları toplumsal yaşamın sanata da bağlı olabilen karmaşık sembolizmlerini barındırır. Mekansal pratik ise üretimi ve yeniden üretimi, toplumsal oluşuma özgü yer ve mekansal kümeleri kapsar; toplumdaki her birey ve mekan arasında bir ilişki tanımlar, süreklilik ve bağlılık sağlar. (Lefebvre, 1974/2012: 33). Birbirinden koparılamaz bu üç inşacı aracılığıyla gerçekleşen sosyal bir üretim olarak kavrandığında, kentsel heykel ve onun tarif getirdiği kamusal alan, durağanlıktan uzak bir anlam geliştirir. Yazı, bu kuramsal çerçevenin oluşturduğu zemin üzerinde, bir mimarlık stüdyosu 
deneyimini, bir reel kent sorunsalı bağlamında aktarmaktadır.

Ankara İskitler kentsel dönüşüm alanı, mekanı sosyal bir üretim olarak algılamamızı sağlayan bu üç momentli süreçin (tasarlanan, yaşanan, algılanan) iç içe geçen karmaşık yapısını anlamaya olanak verir (Lefebvre, 1974/2012: 39-40). Bu alanda kentsel doku, kamusal, yerel ve ekonomik güçler dengesinin etkisiyle yeni bir anlamlanma, yani tasarlanma, yaşanma ve algılanma sürecindedir. Kentsel dokuyla bütünleşik bir toplumsal sanat olgusu kavrayışına, mimarlık stüdyosundan gönderme yapan tasarım problemi, kentsel hafızanın sürdürülebilirliği tartışmalarına katkı sağlamayı amaçlamaktadır.

Maurice Halbwachs'a (1950/1980) göre kollektif hafıza pek çok kez, mekansal bir bileşenle ortaya çıkar. Hafızanın taşıyıcısı bireyler, toplum ve zaman olduğu kadar, mekandırda. Kent(li) mekanları aracılığıyla hatırlar, dolayısıyla, hatırlamak, kentsel kültürün bütünleyici unsurudur. Denilebilir ki, mekansal pratik eş zamanlı olarak hafızaya alma ve hafızada koruma pratiğidir. Pierre Nora'nın (2006) hafıza mekanları kavramsalı, mekana kaydolmuş bir belleği işaret eder. Bu anlayışta, değişime uğrasa $\mathrm{da}$, fiziksel olanla sembolik olanın birbirine tutunmasıyla, kollektif hafıza varlığını sürdürür ve bir sürekliliğe kavuşur. Bu süreklilik ve dirilik, en anıtsal olandan, basit bir sokak adına kadar, mimari kültürün en önemli yansımalarından, sıradan bir konut dokusuna kadar, mekanda ve mekansal olan pek çok unsurda üretilir. Burada mekan kavramı mutlak bir mimari mekanı işaretlemese de, örneğin Uğur Tanyeli'nin (2002) uyarısıyla, tarih de bir hatırlama mekanı olarak kaydedilebilse de, bu çalışma fiziksel mekana odaklanmaktadır. Ancak, yukarıda vurgulandığı üzere, fiziksel mekanın, sosyal bir üretim olduğu yönündeki kuramın benimsenmesi, bu yazının 'hatırlama mekanı' sınırlarını genişletmektedir.

\section{Aşınan Kentsel Hafıza}

Murat Güvenç'in (2012) belirttiği gibi, kent ve kentsel dönüşüm, karmaşık etkileşim süreçlerine bağlı olarak, üzerine konuşmanın zor olduğu konulardır. Kentsel hafıza(sızlık) ile doğrudan ilintili olan kentlilik olgusu ve kentsel dönüşüm hangi arayışların sonucudur diye sorgulamak, kent araştırmalarının önemli ismi Illhan Tekeli'ye (2014) göre, Türkiye'nin sosyopolitik, ekonomik, tarihsel ve kültürel parametrelerine yaşamın içinden bakmayı gerektirir ki böylesi bir kapsamlı bakış, hiç şüphesiz, bu çalışmanın bağlamını aşacaktır. Ancak şu ifade edilebilir ki, Türkiye'de kollektif hafızanın mekanla birlikte, hatta mekan sayesinde var olan bir değer olarak algılanması, pek çok kentsel dönüşüm projesinin aldatıcı ve yapay parlak ışıkları altında baskılanmaktadır. Nitekim, çok sayıda araştırma 
Türkiye'nin mekan ve hafıza ilişkisini, iktidar, kamu otoritesi, tüketim kültürü, rant ve ekonomi gibi bağlamların baskınlığıyla açıklamaktadır (Basa, 2011; Batuman, 2014; Bayhan, 2013; Dai, 2012; Türkün, 2010).

Hızlı kentsel dönüşümler, ardında bıraktıklarına bakmaksızın bir ileri ufuk işaret ederler. Vaat edilen çevrenin kibirli nesnelliği, 'yerine geçme süreçlerini' kolaylaştırıcı bir otorite üstlenir. Mekana ait hafızanın sürekliliği onu hızla istila eden yeni kurgunun (çoğu kez rant kaygılı) baskısıyla aşınır. Kentsel hafıza ise somut karşılığını gündeliklik kesitlerinde bulabildiğinde sürekliliğini korur. Aslında kentsel hafıza diyenitelendirdiğimizilişkilendirme, kentselliğin nüvesi ve onu çok parçalı algılarla ayakta tutan bir soyut bütünlüktür. Hiç şüphesiz, kamusal alanlar, özellikle de tarihsel tanıklıkları olanlar, aktarımlarının gücüne ve akışkanlığına bağlı olarak, kolektif kentsel hafızanın daha yoğunlaştığı yerlerdir. Seçkin anlamlar yüklenmeyen alanlar ise, hafızanın zayıfladığı ya da zayıflamasında sorun görülmeyen imtiyazsız bölgeler diye nitelenebilir. Oysa ki, güçlü imgelere sahip olan alanları, yalıtılmış kent parçaları olarak düşünmek, bu imgelerden yoksun olan kentsel alanların ise gündeliklik olağanlığında oldukları için anlamını eksiltmek, kenti en başından o çok parçalı, çelişkili ve çok katmanlı gerçekliğiyle anlayamamak değil midir? Acaba, kentsel gündelik hayatın sıradanlığını, ve onu üreten mekanların temsil ettiği anlamı, kenti üreten başlıca dinamik olarak tanımamak, hafızayı şekillendirenin gerçekte günlük biriktirmeler olduğunu görmemek midir?

Kentin değişim talep ed(il)en ve bu talep doğrultusunda hemen hemen tamamen üzerindeki yapılardan 'temizlenen' bir bölgesi, Kazıkiçi Bostanları olarak da bilinen Ankara İskitler Endüstri Alanı, yukarıdaki tartışma için bir reel zemin sunmaktadır. Sanayi siteleri, "Ulus'u çevreleyen çöküntü bölgeleri" olarak nitelenmektedir (Bademli, 1987: 51). Ankara Büyükşehir Belediyesi'nce 2003 yılında başlatılan kentsel dönüşüm sürecinin vaadine göre, çoğunluğu oto sanayine ait olmak üzere pek çok sanayi dalına ait iş yerini ve üretim alanlarını barındıran İskitler, beş etaplık bir proje ile yerini modern bir dokuya bırakacak, başkentin en yüksek binası da bu araziden yükselecektir. Yoğun yapılaşmanın öngörüldüğü bir iş merkezine dönüştürülecek alan, figür 1'de görüldüğü üzere şimdilerde bir dramatik kent boşluğu geçici kimliğindedir (Figür 1). Kentsel ölçekli yerin bu geçici kimliği, mimarın toplumsal bağlamdaki rolünü sorgulamaya ve çoğaltmaya dair nadir bir olanak sunmaktır. 


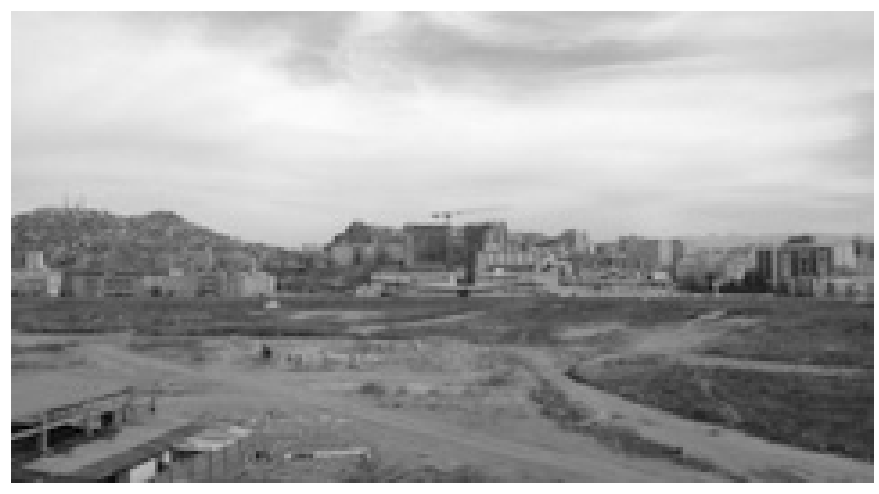

Figür 1: Ankara İskitler, kentsel dönüşüm alanı

Bölge, Gazi Üniversitesi'nin ev sahipliğindeki 2009 yılı Mimari Tasarım Avrupa Kış Okulu'nda da "Kayıp Mekanlar" temasıyla ele alınmıştır (Boyacıoğlu, 2009). Bu kayıp mekanın, tarla ve bostanlarla kaplı olduğu Cumhuriyet dönemi öncesinden, erken Cumhuriyet döneminin 1932 Jansen planındaki hayata geçirilemeyen önerilere, bir sanayi bölgesi olarak geliştiği 1950'ler ve 1957 Yücel-Uybadin imar planı uygulamalarından, 1993 yılındaki Kazıkiçi Bostanları Yeni Kent Merkezi yarışmasına uzanan geçmişi, 2003 yılının kentsel dönüşüm projesiyle Merkezi İş Alanları'na ev sahipliği yapmak üzere yeni mekansal ifadesini aramaya/bulmaya koyulmuştur. Ankara'nın tarihi kent merkezinin hemen çeperinde yer alan ve "Ankara'nın ilk sanayi sitelerinin oluştuğu" (Bademli, 1987: 51) bu üretim alanının dönüşüm kararı, Ankara Metropoliten Alan Nazım Plan Bürosu'nun, Ulus tarihi kent merkezinin korunması öngörüsünün uzantısı olarak, ve "Batı koridorundaki kapsamlı üretim ve konut dokusu gelişimi" çerçevesinde alınmıştır (Keskinok, 2013).

Ulus tarihi kent merkezine yakınlığına rağmen, tarihsel, kültürel ya da estetik koruma mekanizmalarından yoksunluğuyla, bu alan, kentsel hafızanın sürdürülebilirliği konusunda 'dışarıda kalanları' kollayıcı bir tutumun geliştirilebileceği dürtüsünü motive etmektedir. Aslında, sözü edilen mekanizmaların varlığında bile, Ankara'nın, kentsel hafızasını korumakta zora düştüğü, Kızılay Meydanı, Saraçoğlu Mahallesi, Atatürk Bulvarı, Atatürk Orman Çiftliği, Atatürk Kültür Merkezi alanı gibi pek çok tartışmalı mekanda deneyimlenmiştir.

Bu düşünceler bağlamında, Mimarlık Bölümü ikinci sınıf öğrencilerine bir tasarım problemi olarak sunulan alan, pek çok etabı barındıran geniş kapsamlı ve çok ayaklı bir içerikle çalışılmıştır. Kent dokusu çözümlemesiyle başlayıp, önerilen mekansal kurguya uzanan bu süreç, her safhasında 
kentsel hafızanın yitirilmesine karşı mesleki bir refleksi erken aşamada mimar adaylarına kazandırmayı hedeflemiştir. Figür 2'de görüleceği üzere, öğrencilerin alanı fiziksel olarak deneyimlemeleri ve burada gerçekleşecek olan dönüşüm projesi hakkında yetkin bilgi almaları önemsenmiştir (Figür 2).

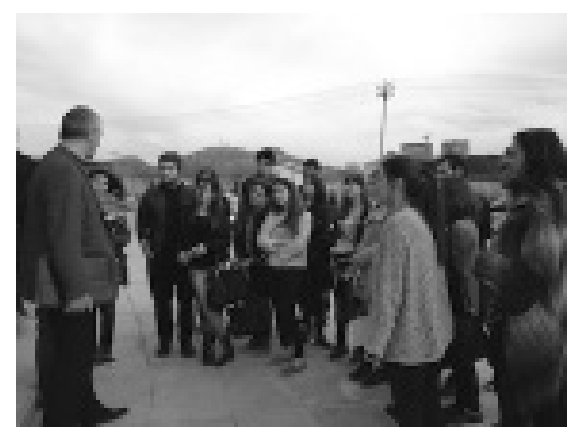

Figür 2: Öğrenciler İskitler alanında

Bu yazının odaklandığı kentsel heykel yaratımı, bir akademik dönemlik sürecin ilk etabı olarak proje içeriğine eklemlenmiş ve takip eden etapların gelişimi yönünde etkin bir uyaran olarak öngörülmüştür. Tasarım probleminin kavramsal bileşeni olarak nitelenebilecek bu etap ile, kentsel hafıza tartışmalarına eleştirel bir katkı getirmek hedeflenmiştir. Projenin devamlılığı içinde, verilen mimari programa uygun mekanların tasarımına yoğunlaşılsa da, sembolik güçleri ile heykeller, tasarım problemini kentsel hafıza ve sürdürülebilirlik kavramları ile zihinlerde buluşturan güçlü birer mekanizma olarak etkilerini sürdürmüştür. Kentsel heykel, bir "iç görünün" kendi "gerçeklik kavranışını" (Yüksel, 2010) toplumsal bir nesneye dönüştüren bir üstdil ve kentliyle yere ilişkin bağ geliştiren bir araç olarak görülmüştür. Kentsel mekanlar için tasarlanan heykellerin kente yaptıkları "estetik katkı" (Güç, 2005) ve "görsel duyum zenginliği" yadsınamaz (Bulat, Yağmur ve Aydın, 2014). Ancak, burada şu belirtilmelidir ki, mimarlık eğitimlerinin dördüncü yarı yılındaki öğrencilerce önerilen kentsel heykeller estetik yönlerinden öte, bilişsel katkılarıyla öne çıkmışlardır.

\section{Temsil Mekanları Yoluyla Kentsel Sahiplenme}

Kentsel hafızaya ait olanı korumak adına önemli bir koşul, kentlide, kentsel olanı sahiplenme içgüdüsünün oluşmasıdır. Bu eğilim, planlamalar ve kurumsal denetlemelerden çok, birey ve mekan arasındaki bağın kentliliğe içkin olan bir yansıması olabilir. Her türlü siyasal veya idari otoriteden soyutlanmış bir kentsel sahiplenme en yüksek ifadeli olandır. Başka bir deyişle, resmi dillerce ifade edilende değil, kentlinin gündelik üslubunda kendine özel yer edindikleri ölçüde, kentsel alanlar kendi gerçekliklerini 
sürdürebilirler. Bu anlamda, sosyal bağlar kurabilen mekanlar, kentsel sürekliliği ve nüansları yutucu dönüşümlerin önünde direnç noktaları oluşturabilirler.

Sadece kentsel mekanın değil, kentsel hafızanın inşasının da kapsamlı bir kuramsal açılımını Henri Lefebvre'in (1974/2012) mekanın sosyal üretimini çözümlediği üçlemesinde dolaylı şekilde bulabiliriz. Üçlemenin bileşenlerinden olan mekan temsili, yani tasarlanan mekan, temsil mekanı olarak anlamını, kentlinin mekansal pratikleriyle kesişmesiyle kazanır. Mekansal pratikler, kentlinin "gündelik yaşam" akışkanlığı içinde (Lefebvre, 1968/2007: 9-10), örneğin, iş yaşamı, kültürel yaşam, serbest zaman ve mesken ağında algıladığı kentsel dokuyu, bireysel hafızasının referansı olarak doğal yolla kodlar. Kentin sadece tarihsel, kültürel merkezi bölgeleri, parklar, meydanlar veya kentlinin bireysel kent mekanlarını kullanım şeması değil, ikincil görülen, yani mekansal pratiklere 'eğreti' şekilde eşlik eden alanlar da bu kodlamada azımsanamayacak role sahiptir.

Endüstriyel üretim alanları, kentlerin hızlı büyümesi karşısında, hafızadan en kolay çözülecek mekanlar olarak görülmektedir. 1970'lerde batı toplumlarında başlayan endüstri mirasını koruma bilinci, günümüzde Türkiye'de de geliştiyse de (Uludağ, 2011), bu bilinç genellikle koruma şemsiyesinin altına alınacak ve yeniden işlevlendirilebilecek yapı gruplarının varlığına eşlik etmektedir. Eğer karlı işlevlerle yenilenerek yaşama eklemlenecek bir yapı stoğu yoksa, böylesi bir kentsel alanın hafızasını koruma gereği de kalmamaktadır; meydan, çevresindekileri yutucu bir yapı oburluğunun acar aktörlerine bırakılmaktadır.

Ne yazıktır ki, yerin hafızasını korumaya almak kentlerin ekonomik gerçekliğiyle bağdaşmaz bir tutuma işaret eder olmuştur. Sosyal sürdürülebilirliğin önemli bir boyutu olan kentsel mekanın karakteri, rant odaklı bakışlara veya siyasal ve idari erkin, yerel yönetimlerin kararlarına göre dönüştükçe, kentlide kentsel sahiplenme duygusu oluşması giderek zorlaşmaktadır. Bu sahiplenme kentin farklı sosyal katmanlarını ve bu katmanların mekansallığını kavrayan bir bütünlüğe ulaşmadıkça, kentli yaşadığı kent üzerine söz söyleme hakkını sorgusuz devretme refleksi geliştirmektedir. Oysa ki, kentliyi, aynı yerleşim alanını paylaşan kitlelerden çok kentsel bağlamda yaşadığı gerçekliği "eleştirebilen bireyler" olarak algılamak (Özden, 2009), nitelikli kentlere sahip olmak için bir ön koşuldur. Kentlinin, mekansal üretimin baş aktörü olduğu çağdaş gerçeği, malesef, Türkiye' de kentsel dönüşüm süreçlerinin rant kaygılarını, siyasal öncelikleri ve tercihleri dışlayan bir sorumlulukla gerçekleşmesini sağlayamamaktadır.

Bu kaygılar yeni nesil mimarlık öğrencilerine aktarılırken, amaç, onları 
bir kentsel farkındalığa yöneltmek ve kamusal bilinçlenme konusunda öncü rollerinin olabileceğini ima etmektir. Jale Erzen'in (2011) kamusal alanlarda heykelin konumu üzerine kaleme aldığı eleştirel metinde altını çizdiği üzere, "kamusal alanlar ve kentlilikle ilgili kültür ve birikimin eksik ve yeni olduğu ülkemizde", bu, azımsanamayacak bir sorumluluk olarak görülebilir. Bir diğer amaç ise, mimarlık stüdyosunda mekan üretimini, mekanı temsil edecek profesyonel düşünceyle ve projelendirme süreciyle sınırlamamanın getireceği anlam çoğalmasını deneyimlemektir. Bu görüşle, öğrencilerin dikkati, yarattıkları mekansal önermelerin kentlinin mekansal pratikleriyle buluşması, güçlü sosyal bağlar aracılığıyla temsil mekanlarına evrilmesi fikrine çekilmektedir. Kentsel bağlamın ve kaybolan kentsel hafıza sorunsalının şekillendirdiği bir mekansal üretim kurgusunda, kentsel hafızanın korunmasında sembolik gücünün pek çok araştırmada vurgulandığı kentsel heykelin (Acar, 2014; Ertuna, 2005; Kurtaslan, 2005; Loeb, 2009; Sharp, Pollock, Paddison, 2005), proje sürecine ilham vermesi beklenmiştir. Yani, denilebilir ki, genç mimar adaylarını mimarlık stüdyosu platformunda kamusal sanata yönelten düşünceyi meşrulaştıran, onların heykelin mekansal gücünü keşfetmelerine olanak sağlamak ve böylelikle "pratik-duyumsal mekanın" (Lefebvre, 1974/2012: 73-74) kentliyle birlikte üretileceği yaklaşımını olgunlaştırmaktır.

\section{Mimar Adayının Kentsel Aydınlanması: Sürdürülebilirlik Üzerine bir Mimarlık Stüdyosu Deneyimi}

Mimarlık okulları birbirlerinden farklı vizyonlara ve yapılara sahip olsalar $\mathrm{da}$, tasarım stüdyoları neredeyse istisnasız olarak mimarlık eğitiminin merkezinde yer alır. Bu stüdyolarda, eleştirel düşüncenin eşlik ettiği tasarım problemleri aracılığıyla, mekansal üretimin yaratıcı / profesyonel / teknik boyutları, ve bunun yanı sıra, toplumsal yönü vurgulanır. Elbette bu vurgular stüdyonun önceliklerine, eğitim stratejilerine ve dönemin öne çıkan paradigmalarına göre farklılıklar gösterebilir. Mimarlık öğrencilerine verilecek "tasarım problemini himaye edecek proje konusunu", diğer konuları tasfiye ederek öne çıkaran göreli unsur, aslında konunun stüdyo yöneticilerinin vurgulamak istedikleri bir yan anlam ile örtüşme kapasitesidir (Basa, 2010).

Ankara Expo Centre -Sustainable Urban Thinking (Sürdürülebilir Kentsel Düşünce), başlığıyla verilen proje, yerin endüstriden beslenen hafızasının yok olmamasına özenilerek seçilmiş ve bu hafızaya göndermeler yapan bir mimari tasarım problemi olarak sunulmuştur. Ankara'da, kapsamlı ve hızlı bir dönüşümün yaşandığı eski endüstri bölgesi İskitler'e odaklanılan proje, alanın endüstriyel, sosyal ve tarihsel hafızasını ve karakterini vurgulayarak 
yeni oluşumlar yaratmak için ideal bir olanak sağlamaktadır. Stüdyonun baskın düşünsel niteliğini oluşturan sürdürülebilirlik yaklaşımı, belli bir yere kimlik ve karakterini veren ekonomik, sosyal, kültürel ve çevresel boyutları kapsamaktadır. 'Sürdürülebilir gelecek' temalı Ankara Expo Centre -uluslararası sergi ve fuar alanı, bu önemli kentsel alanın çevresel ve sosyal bağlamlar gözetilerek yaşama tekrar kavuşturulmasına bir örnek oluşturmaktadır. Sürdürülebilirlik, malzeme seçiminde yerel kaynaklara öncelik vermekle başlayıp, yapıların gelecekte tekrar işlevlendirilebilme potansiyeline uzanmakta, ancak bununla sınırlanmamaktadır. Yerin tarihsel süreç içindeki tanıklıklarını, Ankaralı için belleklerde ismiyle örtüşük anlamlarını, kent bütünü içinde algılanagelen karakterini yok farz etmemek, yani geniş anlamıyla, sosyal sürdürülebilirlik stüdyonun mimari tasarım yaklaşımının belirleyicisi olmuştur. Projede bir kentsel dış mekan heykeli, yeşil alanlar, kalııı ve geçici fuar sergi alanları, konferans salonları ve sürdürülebirlik kriterleriyle tasarlanmış bir ofis bloğunun yanısıra, mekanın kamusal karakterini vurgulamak adına, geleceğin sürdürülebilir endüstrilerine odaklanılan müze ve kütüphane bulunmaktadır. Yapılı alanlar en fazla üçte bir oranında tutulmakta, üçte iki oranında (veya öğrencinin önerisine göre daha yoğun) yeşil alan ve su yüzeyleri önerilmektedir.

Proje kapsamında, Ankara İçin Dış Mekan Heykeli -Bir Kentsel Jest (Outdoor Sculpture for Ankara -An Urban Gesture) başlığıyla ve kentsel sürdürülebilirlik temasıyla verilen ön projede, sanatın kentsel kamusallağın çok önemli bir parçası olduğu vurgulanmıştır. Türkiye'deki algı bu bakışı tam olarak yansıtmasa da, kamusal sanat, kentsel mekanın üretiminde, bir aidiyet ve topluluk duygusu yaratma kabiliyetiyle, mekansal dokuyu zenginleştirici tematik ve estetik nitelikleriyle, kentsel sürdürülebilirliğin ve yaşanırlığın önemli bir unsurudur. Bu proje bağlamında da kentsel heykelin, günümüz kentlerinin sıradanlığının üstesinden gelme, kentsel unutkanlığa direniş ve kentliye temsil mekanları açılımı sunabilme potansiyelinin altı çizilmiştir. Eski bir endüstriyel bölgede konumlanacağı bilgisi öğrencilere genel bir kavramsal çerçeve sunmuş ve süreci motive eden bir dinamiğe dönüşmüştür. Öğrenciler tasarlayacakları heykelin temsil gücünün dönüş(türül)me sürecindeki bu bölgenin baskın niteliği olan endüstri referansından besleneceği yönünde bilinçlendirilmiştir. Hem sürdürülebilecek bir kentsel anlam olarak, hem de heykelin yer alacağı alanın özgün bir kodlaması olarak endüstrinin altı çizilmiştir. Üretim ilişkilerinin değişmesinin bu eski endüstriyel bölgede sosyo-mekansal bir dönüşüme tanıklık edecek olması vurgusu öğrencilerin heykel tasarımlarını endüstriinsan-çevre-kent odaklı düşünmeye yöneltmiştir. Sürdürülebilirlik kavramı, kentin hafızasını endüstri temalı bir heykelle sembolik bir korumaya almak ve temiz bir çevreye işaret eden doğa dostu bir endüstriyi olumlamak olarak 
öğrencilerce iki yönlü ele alınmıştır. Böylelikle, sürdürülebilirlik, sosyal ve çevresel olmak üzere her iki bağlamı da eşdeğerli barındıran bir gerçeklik olarak betimlenmiştir.

En fazla $5 m \times 5 m \times 5 m$ boyutlarında olması öngörülen ve 1/10 ölçeğinde modellerle temsil edilen heykeller, malzeme seçiminden, biçime, soyut düşünceden, yere aidiyetine kadar, Ankara Expo Centre -sürdürülebilir kentsel düşünce dönem projesinin kentsel gerçeklik ve kamusal sanat bağlamları arasında hafıza arayüzü olmuştur. Ankara'nın İskitler endüstri bölgesinin (şimdilerde kaybedilmekte olan) hafızasının da, bir metabolizma olarak kavramsallaştırılabilecek kentin, sürdürülebilir belleğinin parçası olduğu yönündeki anlayışın yol göstericisi olan heykeller, aşağıda üçöğrenci projesi ile örneklendiği üzere birbirinden farklı yorumlarla nesneleşmiştir. Endüstri temalı heykeller, öğrencilerin ikinci aşamada gerçekleştirecekleri mimari/kentsel projede, 'yerin' endüstriyel geçmişini kodlayan sembolik öğeler olarak işlevlenmiştir.

23 öğrencinin bulunduğu stüdyoda her öğrenci endüstriyel bir alanın hafızasını sembolize edecek yaratıcı bir yaklaşımla heykellerini tasarlamış, endüstriyi değişik bağlamlarda ele almıştır. Örneğin, bir öğrenci heykel çalışmasında endüstri temasını, üretimi ve çevre sorunsalını temsil ettiği fikriyle fabrika yapısı soyutlamasıyla işlemiştir (Figür 3, Figür 4). İkinci öğrenci çalışmasındaki vurgu, endüstri, doğa ve insan ilişkisi bağlamına yapılmıştır (Figür 5, Figür 6). Son örnekte ise endüstri ve kent bağı, düzen ve kaos ikililiği üzerinden temsil edilmiştir (Figür 7, Figür 8).

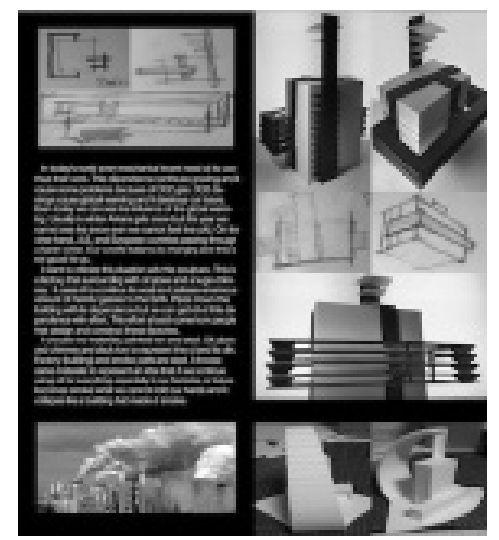

Figür 3: Öğrenci (Alp Köse), kentsel heykel kavramsal paftasında endüstri ve çevre ilişkisini soyut fabrika yapısı formuyla ele alan heykelini betimlemekte, tasarım süreçini yaptığı ön skeçlerle ve modellerle aktarmaktadır. 


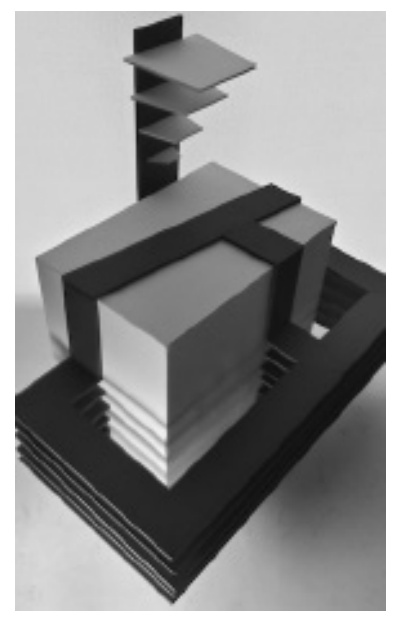

Figür 4: Alp Köse, kentsel heykel projesi

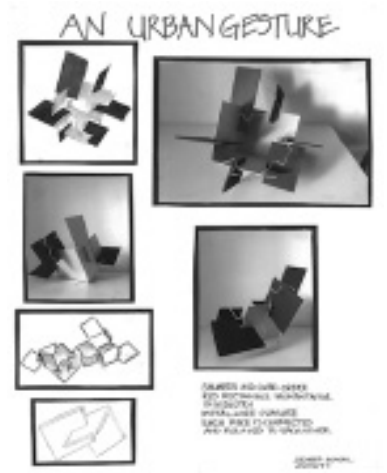

Figür 5: Öğrenci (Zeynep Soysal), kentsel heykel kavramsal paftasında endüstri ve insan ilişkisini soyutladığı çalışmasındaki farklı renklerin ve formların anlamlarını aktarmaktadır. Örneğin, heykeldeki tek 'kırmızı' parka, insan faktörünü, endüstriyi temsil eden geometrik formlara dolanan metal ise doğayı temsil etmektedir.

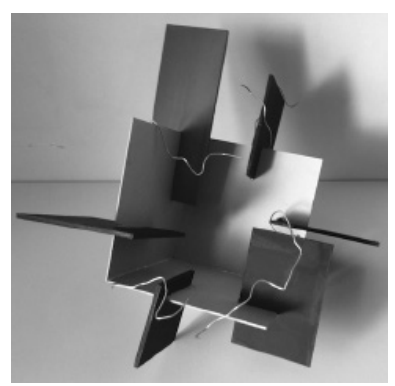

Figür 6: Zeynep Soysal, kentsel heykel projesi 


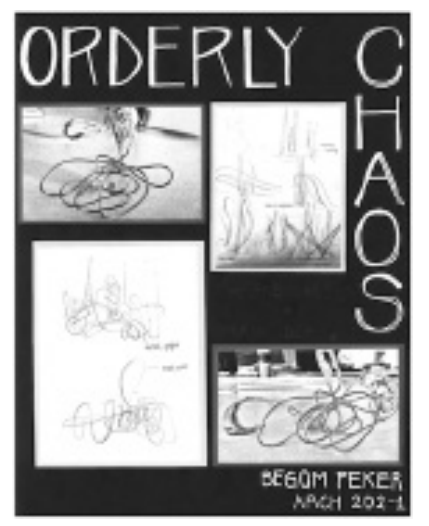

Figür 7: Öğrenci (Begüm Peker), kentsel heykel kavramsal paftasında düzenle ilişkilendirdiği endüstri ve karmaşık bir bünye olarak tariflediği kentin ikililiğini, bunların parçalı bütünlüğünü nasıl soyutladığını grafik olarak aktarmaktadır.

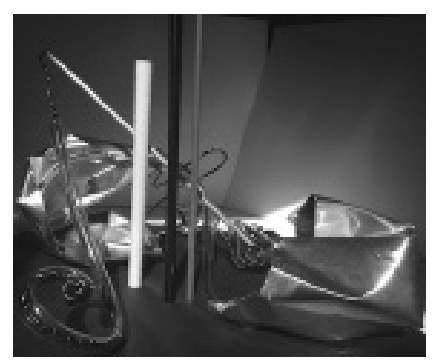

Figür 8: Begüm Peker, kentsel heykel projesi

Yukarıda örnekleri sunulan kentsel heykeller, stüdyoda bunu izleyen süreçteki ana mimari projenin, yerin tarihsel kimliğini hatırlatacak mekansal pratiklere atıfla gelişmesi yolunda bir farkındalığın sembolik temeli olmuştur. Bu farkındalık önemlidir, çünkü öğrencilere çalışmak üzere verilen bu arazideki reel gelişmeler İskitler bölgesini tüm geçmiş kodlarından sıyırıp kimliksizleştirmektedir. Üzerinde iş makinalarının çalıştığı, 2017'de bitmesi planlanan projesinin (MiA -Merkezi İş Alanları Projesi) bir büyük iş merkezi dokusunu dikte ettiği (brüt $640.000 \mathrm{m2}$, net $312.000 \mathrm{~m} 2$ ) alan için, kimliğini sürdürme hakkı, mimarlık öğrencilerinin endüstri vurgusuyla kentsel hafızaya göndermeler yapan mimari projelerinde ses bulmuştur. Üretkensizleştiği ve ekonomik ömrünü tamamladığı için metruklaştığı gibi gerekçeler, alanın bütünüyle boşaltılması fikrini ve inşa edilecek olan bir ticaret-tüketim yoğunluklu, arazi değeri yüksel(til)miş "çağdaş kent merkezi'nin" daha ekonomikaltyapısınıbeslerken, Ankaralıçin hafızalardan bir görüntü daha silinmekte, bir kentsel anlam daha eksilmektedir. 


\section{Bitirirken}

Bu çalışmaya konu olan İskitler bölgesi, Theodor Adorno'nun günümüzde "kültürün herşeye benzerlik bulaştırdığı" teşhisindeki gibi bir saptamayı (2007: 19) kentsel dönüşüm için akla getirmektedir. Yıkıp, islah ederek yeniden yapmaya programlı süreçler, yerin farklılığını kentsel kültürün parçası olarak düşünmeye vakit ayıramayacak bir telaşiçindedir. İskitler' deki halihazır bitmemişlik, hem stüdyoya hem de bu yazıya bir bakış açısı aralamıştır. Bu kent parçası, bellek silici, dayatmacı, tekilleştirici ve yabancı bir bitmişliğe henüz kavuşmadığından, hüküm süren "muğlak bitmemişlik" hala, bir kentsel "umut barındırmaktadır" (Basa ve Zelef, 2011: 165). 1950'den başlayarak başkentin ilk sanayi sitelerine (Yeni Sanayi Çarşısı, Büyük Sanayi ve Ata Sanayi Çarşıları, Demir Sanayi Çarşısı) ev sahipliği yapmış bu alanın, kentsel kültürün sürekliliğindeki izlerinin tamamen yok olması, kentsel hafızayı, mümkün olan her zemin üzerinde, tartışılması gereken bir sorunsal olarak işaret etmektedir.

Kentsel kültür, mekanın içinde biriken değerler ve yaşantı değil, mekansal gerçekliğin kendisi olarak var olur ve mekansal pratikle varlığını sürdürür. Bu anlayışla, Ankara İskitler bölgesine odaklanılan tasarım stüdyosu projesi aracılığıyla öğrencilerden beklenen, tasarlanmış ve düzenleyen bir nesne-mekan ilişkisi yerine, mekansallıkla yaşanacak olanın tahayyülüdür. Bu tahayyülün omurgasını kentlinin gündelik yaşam örüntülerinde izleri sürülebilecek bir sosyo-mekansal geçmişin yok sayılmadığı bir tasarım anlayışı kurgulamaktadır. Bu bir anlamda, "imgelemin nüfuz edeceği" ve "duyumsal bir çekirdeği olan" (Lefebvre, 1974/2012: 41) temsil mekanının ön kurgusudur. Bu kurgu, eş zamanlı olarak, otoriter ve bilgiç kentsel dönüşüm projelerinin ve bu çerçevede üretilmiş mekan temsillerinin örtük eleştirisidir.

Türkiye'de dönüşüm projeleri, yerin kendine has kimliğini ve bünyesinde türlü kodlarla var ettiği egemen veya saklı nitelikler bütününü 'ezip baskılayan' nitelikleriyle dikkat çekmekte, 'tasarlanmış/tasarlanacak' kentsel alanlar olarak hep bir farklılık vurgusu yapmaktadırlar. Bu hesaplı vurguyla projelendirilen ve inşa edilen 'slogan mekanlar', Lefebvre'in deyişiyle, "farklı bir mekansal pratiği kademeli olarak gün ışığına çıkarmak yerine" (1974/2012: 59) çoğu kez gündelik yaşamı tümden başkalaştırmak ve kalitesini arttırmak stratejisine göre programlanırlar. Sentetik stratejilerin ürettiği mekan temsillerinin gerçekliği, mekanın algılanan ve yaşanan toplumsallığını, hatta belleğini inşa edebileceği sanısına denk düşer. Bu sanının kuşkulu araçsallığının sorgulanması ise bir kentlilik gereği ve sorumluluğu olarak belirir. 


\section{Kaynakça}

Adorno, T. W. (2007). Kültür Endüstrisi, Kültür Yönetimi (çev. N. Ülner, M. Tüzel ve E. Gen). İstanbul: iletişim Yayınları.

Bademli, R. (1987). Sanayinin Yerseçimi Süreçleri., ODTÜ Şehir ve Bölge Planlama Bölümü Çalışma Grubu, Ankara Büyükşehir Belediyesi EGO Genel Müdürlüğü, Ankara 1985'den 2015'e. Ankara: Ajans Illetim, s. 49-54.

Basa, i. (2011). Kültür Göndergesinin Karmaşıklığı: Kentsel (Gündelik) Yaşamın Aydınlanma Mekanı veya Şenlikçi Alanı olarak Ankara Atatürk Kültür Merkezi. Dosya, TMMOB Mimarlar Odası Ankara Şubesi, 27, s. 32-40.

Basa, i. (2010). Project Selection in Design Studio: Absence of Learning Environments. The Educational Forum, 74(3), s. 213-226.

Basa, I., Zelef, H. (2011). Kent kültürü tartışmalarında muğlak rolleriyle Ankara'nın bitmemiş yapıları., E. O. Incirlioğlu ve B. Kılıçbay. (Editörler). Mekan ve Kültür. Ankara: Tetragon Iletişim, s. 157-166.

Batuman, B. (2014). Saraçoğlu 2013: Kentsel Bellekte ve Kent Mücadelesinde bir Mevzi. Mimarlık, Mimarlar Odası, Ocak-Şubat, 375, s. 22-23.

Bulat, S., Yağmur, Ö., ve Aydın, B. (2014). Kamusal Mekan ve Heykel. Asos Journal, 2(6), s. 450-461.

Dai, C. M. (2012). Yer Kuramının Temellerine Göre, Yerin Dönüşümü: Atatürk Bulvarı. Dosya, TMMOB Mimarlar Odası Ankara Şubesi, 28, s. 32-37.

Ertuna, C, (2005). Kızılay'ın Modernleşme Sahnesinden Taşralaşmanın Sahnesine Dönüşüm Sürecinde Güvenpark ve Güvenlik Anıtı. Planlama, TMMOB Şehir Plancıları Odası Yayını, 34, s. 6-15.

Erzen, J. N. (2011). Kamu Alanlarında Heykel ve ifade Özgürlüğü. Mimarlık, Mimarlar Odası, Mart-Nisan, 358, s. 10-11.

Güç, M. (2005). Açık Alan Heykellerinin Kent Estetiğine Katkısı. Çukurova Üniversitesi Sosyal Bilimler Enstitüsü, Yayımlanmamış Yüksek Lisans Tezi, Adana.

Güvenç, M. (2012). Kent Tarihi Işığında Kentsel Dönüşüm. Dosya, TMMOB Mimarlar Odası Ankara Şubesi, 28, s. 120-124.

Halbwachs, M. 1980 (1950). The Collective Memory. New York: Harper \& Row.

Harvey, D. 2008. Umut Mekanları (çev. Z. Gambetti). İstanbul: Metis Yayınları. (Eserin orijinali 2002'de yayımlandı). 
Keskinok, Ç. (2013). Ankara'nın Planlanması, Ulus Tarihi Kent Merkezi ve Raci Bademli. METU Journal of Faculty of Architecture, 2, s. 224-225.

Kurtaslan, B. Ö. (2005). Açık Alanlarda Heykel-Çevre Ilişkisi ve Tasarımı. Sosyal Bilimler Enstitüsü Dergisi, 18(1), s. 193-222.

Lefebvre, H. 2007. Modern Dünyada Gündelik Hayat (çev. I. Gürbüz). İstanbul: Metis Yayınları. (Eserin orijinali 1968'de yayımlandı).

Lefebvre, H. 2012. The Production of Space (çev. D. Nicholson-Smith). Malden: Blackwell. (Eserin orijinali 1974'de yayımlandı).

Loeb, C. (2009). The City as Subject: Contemporary Public Sculpture in Berlin. Journal of Urban History, 35(6), s. 853-878.

Nora, P. (2006). Hafıza Mekanları (çev. M. E. Özcan). Ankara: Dost Kitabevi Yayınları. (Eserin orijinali 1989'da yayımlandı).

Özden, L. (2009). Gizli Dehlizlerden Kent Alanlarına Dışavurum Yüzeyi Olarak Duvar. Sanat ve Tasarım Dergisi, Gazi Üniversitesi, Güzel Sanatlar Fakültesi, Haziran, 3, s. 71-85.

Sharp, J., Pollock, V. and Paddison, R. (2005). Just Art for a Just City: Public Art and Social Inclusion in Urban Regeneration. Urban Studies, 42(5-6), s. 1001-1023.

Tanyeli, U. (2002). Önsöz., A. Cengizkan. Modernin Saati. Ankara: Mimarlar Derneği 1927 ve Boyut, s. 7-8.

Tekeli, i. (2014). Kent, Kentli Hakları, Kentleşme ve Kentsel Dönüşüm. İstanbul: Tarih Vakfı Yurt Yayınları.

Türkün, A. (2010). İstanbul'da Kentsel Dönüşüm: Mali Kaynak Yaratma Aracı Olarak Kent. Mimarlık, Mimarlar Odası, Kasım-Aralık, 356, s. 42-43.

Uludağ, Z. (2011). Kamusal Alanda Yeni Bir Deneyim; Değişen Mekansal Pratikler ve Ankara Cer Atölyeleri., E. O. İncirlioğlu ve B. Kılıçbay, (Editörler). Mekan ve Kültür. Ankara: Tetragon Iletişim, s. 149-155.

Yüksel, M. (2010). Günümüz Figüratif Heykelinde Gerçeklik Olgusunun Simulakr Gerçekliğiyle Yansıması. Sanat ve Tasarım Dergisi, Gazi Üniversitesi, Güzel Sanatlar Fakültesi, Haziran, 5, s. 181-191. 


\section{İnternet Kaynakları}

Internet: Acar, M. E. (2014). Dilsiz Anıtlar. Mimarlık. Eylül-Ekim, 379. Web:http:// www.mimarlikdergisi.com/index.cfm?sayfa=mimarlik\&DergiSayi=393\&ReclD=3491 adresinden 28 Kasım 2014'de alınmıştır.

Internet: Bayhan, B. (13.Aralık.2013). Hafıza mekanları. Arkitera. Web: http://www. arkitera.com/haber/18781/hafiza-mekanlari adresinden 1 Aralık 2014'de alınmıştır.

Internet: Boyacıoğlu, E. (2009). Mimari Tasarım Avrupa Kış Okulu EWSAD 2009. Mimarlık. Mart-Nisan, 346. Web: http://www.mimarlikdergisi.com/index. cfm?sayfa=mimarlik\&DergiSayi=360\&RecID=2008 adresinden $28 \mathrm{Kasım} 2014$ 'de alınmıştır.

\section{Görsel Kaynakları}

Figür 1: Fotoğraf, İnci Basa, 2014

Figür 2: Fotoğraf, İnci Basa, 2014

Figür 3: Fotoğraf, İnci Basa, 2014

Figür 4: Fotoğraf, Alp Köse, 2014

Figür 5: Fotoğraf, İnci Basa, 2014

Figür 6: Fotoğraf, Zeynep Soysal, 2014

Figür 7: Fotoğraf, İnci Basa, 2014

Figür 8: Fotoğraf, Begüm Peker, 2014 